tinue to have responsibility for long range planning, decision making and some administration of the library.

The sun/dust fireworks filling the now almost empty office, while inadequate to the task, provide a festive celebration of Rotation Day, a day noteworthy in the library world for its liberating effects. In fact, in some measure, it is the Bastille Day or the 4 th of July for the Boyd Lee Spahr Library. In the same way that people celebrated the fact that one social class was no longer subservient to another or that the colonists were no longer subject to the king, librarians on Rotation Day celebrate freedom from dehumanizing hierarchy and debililating competition and division. When all librarians share equally the responsibilities and rewards of librarianship, they are free to realize their full potential; they become fully human. Rotation Day is, then, an appropriate occasion for celebrating the boundless potential, individual and corporate, of librarians to contribute to education and to the preservation and growth of knowledge.

\title{
ACRL continuing education courses
}

\section{at the Midwinter Meeting}

The Association of College and Research Libraries will sponsor four continuing education courses at the ALA Midwinter Meeting in Chicago. Advance registration by December 23,1985 , is required. A late registration fee of $\$ 15$ will be charged.

A Certificate of Completion will be awarded participants in each course. Successful completion of 10 contact hours of continuing education is equal to one Continuing Education Unit (CEU). ACRL maintains a CEU record for each participant.

To register, send in a completed registration form to Sandy Donnelly, ACRL/ALA, $50 \mathrm{E}$. Huron Street, Chicago, IL 60611. Details of the courses follow:

\section{Performance Evaluation: \\ A Results-Oriented APPROACH}

CE 106 will introduce participants to the concept of performance evaluation based on performance goals and results-oriented evaluation. This includes explanation of different approaches and purposes for evaluation; review of how a goalsbased performance system works; practice writing performance goals; discussion of how to improve a poor evaluation system; meeting conflict in evaluation interviews; and how to make evaluation a developmental experience for the supervisors and the employee.

Instructor: Lucy Cohen, Manager of Personnel and Payroll, University of Michigan Libraries.

Date: Friday, January 17, 9:00 a.m. $-5: 00$ p.m.

Fee: ACRL members $\$ 95$; non-members $\$ 135$.

CEUs: $7 \mathrm{CEU}$.

\section{Operating and Marketing Fee-Based SERVICES IN ACADEMIC LIBRARIES: A SMall Business ApProaCH}

CE 108a provides information to enable administrators and librarians from academic libraries and especially operating managers with the tools to critically analyze fee-based service operations. Participants are urged to bring any existing service brochures, price schedules, policy statements and business plans with them to the program. These documents will be especially useful during the working portion of the program.

Instructor: Barbara Stump, Director, Regional Information and Communication Exchange, Rice University Library.

Date: Friday, January 17, 9:00 a.m. $-5: 00$ p.m. Fee: ACRL members \$95; non-members \$135. CEUs: 7 CEU.

\section{Imphoving Job Performance: STRATEgIES For SUPERVISORS}

CE 112 will help librarian-supervisors create a climate for motivation, define job competencies, set performance standards, address performance problems and improve work effectiveness of their staff. This course is intended for librarians who are first-line supervisors or middle managers. Past participants to CE 101 note: the material presented in this course will build upon the knowledge and skills developed in ACRL CE 101 Librarians as supervisors.

Instructor: Maureen Sullivan, Head of Personnel, Yale University Library.

Date: Friday, January 17, 9:00 a.m.-5:00 p.m Fee: ACRL members $\$ 95$; non-members $\$ 135$. CEUs: 7 CEU.

\section{Creative Approaches to Video for BIBLIOGRAPHIC INSTRUCTION}

CE 206-It is estimated that over 600 academic librarians have produced videotapes for bibliographic instruction. This workshop examines uses of video, critical production issues, and a financial comparison of various media products. Many examples of library video products will be examined. In addition, creative problem solving techniques will be applied to the process of developing a videotape project. A number of exercises designed to enhance creative potential will be conducted.

Instructor: Thomas McNally, Head Circulation 


\title{
REGISTRATION FORM
}

\author{
CONTINUING EDUCATION COURSES
}

\section{PLEASE PRINT}

NAME

AFFILIATION

STREET

(indicate home or work)

CITY

STATE

ZIP

DAYTIME PHONE

ALA/ACRL MEMBERSHIP \#

SOCIAL SECURITY \# (essential for CEUs)

\section{PLEASE CIRCLE THE APPROPRIATE DOLLAR AMOUNT FOR THE COURSE OF YOUR CHOICE, AND INDICATE YOUR PREFERENCES IN THE MARGIN (1st, 2nd.).}

Course ACRL Member Non-member

CE 106 Performance Evaluation: A Results Oriented Approach (January 17)

$\$ 95 \$ 135$

CE 108 Operating and Marketing Fee-Based Services in

Academic Libraries: A Small Business Approach (January 17)

CE 112 Improving Job Performance: Strategies for Supervisors (January 17)

CE 206 Creative Approaches to Video for Bibliographic (January 17)

ENTER TOTAL AMOUNT ENCLOSED

*Fee for registration after December 13.

PAYMENT (check one) check

(enclosed) VISA

Expiration Date

CONFIRMATION: Written confirmations will be made.

CANCELLATIONS: Written notice of cancellations received by December 23 will be honored subject to a $\$ 15$ cancellation charge. No refunds for cancellations after December 23 .

You may make checks payable to ACRL and return them with this form to:

ACRL-Continuing Education

American Library Association

50 E. Huron St.

Chicago, IL 60611 


\title{
University Libraries Section news
}

\author{
By Shelley Phipps \\ Chair, ACRL University Libraries Section
}

\section{ULS activities in 1985-86.}

$\mathbf{I}_{\mathrm{n}}$ $n$ an effort better to communicate with the many members of the University Libraries Section, the ULS Steering Committee agreed at its meeting during Annual Conference to utilize C $U R L$ News rather than tax the resources of ACRL for an additional section newsletter. The summary of section activities that follows is brief; the chair welcomes any questions or responses.

Steering Committee Appointments. Karen Seibert, University of North Carolina, and Patricia Swanson, University of Chicago, have been appointed to serve three-year terms on the Steering Committee. They join Julia Woods, Florida International University; Leon Raney, South Dakota State University; Murray Martin, Tufts University; and Janice Koyama, University of California, Berkeley, as members-at-large. Donna Goehner, Western Illinois University, has been elected vicechair/chair-elect, and Martha Bowen, University of Louisville, has been appointed ULS liaison to the ACRL Board of Directors.

Section Review Committee. Cynthia Duncan, past ULS chair, will be holding a hearing during the ALA Midwinter Meeting on Sunday, January 19, from 9:30 to 11:00 a.m. The hearing will provide the opportunity for all members to participate in setting the Section's objectives and directions for the coming years. Are your interests being served? Are there issues for which you think the University Libraries Section should serve as the forum for discussion? Is there work to be done on certain na- tional projects of interest to all university libraries? Should there be working committees within the University Libraries Section? Come and join in the discussion, and help make our section responsive to your interests.

Standards for University Libraries Review Committee. Kent Hendrickson, University of Nebraska, Lincoln, has agreed to chair this important committee. The Standards, approved by ACRL in 1979 , will be reviewed and recommendations for changes and updating will go to the Standards and Accreditation Committee for review and ultimately to the ACRL Board for ratification. During the Midwinter Meeting the Committee will hold a hearing on Sunday, January 19, from 2:00 to 4:00 p.m. Copies of the current Standards are available from the ACRL Office at no charge for those who wish to participate in the review. They were last published in C\&RL News, April 1979, pp.101-10. Kent welcomes any written comments, and your presence at the hearings will help the Committee determine the focus of their review and a sense of the community's need for updating the Standards.

The Mission of an Undergraduate Library (Model Statement). The ULS Steering Committee accepted the excellent report submitted by the Committee, chaired by Thomas Fry, that was charged with reviewing and updating the 1979 ACRL Mission of the Undergraduate Library Model Statement, and forwarded it to the ACRL Standards and Accreditation Committee. Anyone 